\title{
Pozbawienie wolności w celu zbadania stanu psychicznego $\mathrm{w}$ prawie polskim
}

\author{
Teresa GardockA \\ ORCID: 0000-0002-2923-9379 \\ Katedra Prawa Publicznego \\ Wydział Prawa \\ SWPS Uniwersytetu Humanistycznospołecznego w Warszawie
}

Konstytucja Rzeczypospolitej Polskiej w art. 41 zapewnia nietykalność i wolność osobistą. Określa jednocześnie, że pozbawienie lub ograniczenie wolności może nastąpić tylko na zasadach i w trybie określonych w ustawie.

W Konstytucji opisano również ogólne przyczyny uzasadniające ograniczenia wolności konstytucyjnych, wymieniając w art. 31 ust. 3 ogólne podstawy uzasadniające ustawowe ograniczenia. Są to: bezpieczeństwo lub porządek publiczny, ochrona środowiska, zdrowie i moralność publiczna, wolności i prawa innych osób. Okoliczności te uzasadniają ograniczenia, jeżeli nie naruszają one istoty owych wolności i zarazem są konieczne w demokratycznym państwie.

Każda określona ustawą możliwość pozbawienia człowieka wolności musi być zatem poddana analizie pod względem konieczności jej wprowadzenia w demokratycznym państwie i okoliczności, które tę konieczność uzasadniają. Instytucja pozbawienia wolności jest najściślej związana z prawem karnym, w którym występuje jako kara ${ }^{1}$, jako

${ }^{1}$ Zobacz katalog kar w kodeksie karnym — art. 32. 
środek zapobiegawczy ${ }^{2}$ oraz w postaci zatrzymania osoby podejrzanej (art. 244 k.p.k.) lub innych osób (zob. art. 15 ustawy o Policji ${ }^{3}$ czy też art. 285 § 2 k.p.k. odwołujący się do zatrzymania świadka). Zatrzymania dotyczy art. 41 ust. 3 Konstytucji. Jest to instytucja o swoiście określonych podstawach, zwykle związanych z podejrzeniem popełnienia przestępstwa, chociaż niekoniecznie ${ }^{4}$. Przykładem niepowiązania z podejrzeniem popełnienia przestępstwa jest zatrzymanie do wytrzeźwienia przewidziane w art. 40 tej ustawy.

Pozbawienie wolności w celu zbadania stanu psychicznego pojawia się w polskim prawie w czterech ustawach:

- w kodeksie postępowania karnego dopuszczalne jest pozbawienie wolności oskarżonego/podejrzanego celem zbadania stanu psychicznego; badanie ma określić poczytalność;

— w ustawie o ochronie zdrowia psychicznego ${ }^{5}$ osoba, u której podejrzewa się chorobę psychiczną, może być umieszczona w zakładzie leczenia psychiatrycznego celem ustalenia, czy cierpi na chorobę uzasadniająca leczenie bez zgody;

- ustawa o wychowaniu w trzeźwości i przeciwdziałaniu alkoholizmowi ${ }^{6}$ dopuszcza możliwość umieszczenia w zamkniętym zakładzie leczniczym na okres 2 tygodni, z możliwością przedłużenia do 6 tygodni, celem ustalenia istnienia uzależnienia od alkoholu;

- kodeks postępowania cywilnego dopuszcza umieszczenie osoby, wobec której wszczęto postępowanie o ubezwłasnowolnienie, w zakładzie zamkniętym leczenia psychiatrycznego celem zbadania, czy istnieją przesłanki ubezwłasnowolnienia (art. 554).

Nie mam wątpliwości, że instytucje wymienione w trzech pierwszych punktach są ograniczeniem prawa do wolności osobistej ze wzglę-

2 Tymczasowe aresztowanie jest uregulowane w kodeksie postępowania karnego $\mathrm{w}$ art. $249 \mathrm{n}$.

${ }^{3}$ Ustawa z dnia 6 kwietnia 1990 roku o Policji (tekst jedn. Dz.U. z 2019 r. poz. 16).

${ }^{4}$ Przykładowo ustawa o wychowaniu w trzeźwości i przeciwdziałaniu alkoholizmowi dopuszcza zatrzymanie osoby i umieszczenie jej w izbie wytrzeźwień na czas nieprzekraczający 24 godzin (art. 40).

5 Ustawa z dnia 19 sierpnia 1994 roku o ochronie zdrowia psychicznego (tekst jedn. Dz.U. z 2018 r. poz. 1878).

${ }^{6}$ Ustawa z dnia 26 października 1982 roku o wychowaniu w trzeźwości i przeciwdziałaniu alkoholizmowi (tekst jedn. Dz.U. z 2019 r. poz. 2277). 
du na bezpieczeństwo i porządek publiczny oraz wolności i prawa innych osób.

Obserwacja psychiatryczna w zakładzie zamkniętym może mieć miejsce podczas procesu karnego na obu jego etapach, czyli zarówno w postępowaniu przygotowawczym, jak i sądowym, na wniosek powołanych biegłych (art. 203 k.p.k.), gdy na podstawie jednorazowego badania nie są w stanie ocenić poczytalności oskarżonego. Poczytalność ma fundamentalne znaczenie dla odpowiedzialności oskarżonego, która jest oparta na winie (art. $1 \S 3$ k.k.). Niepoczytalność zdefiniowana w art. 31 k.k. wyklucza możliwość przypisania winy, wyklucza zatem odpowiedzialność karną. Ustawodawca musi natomiast przewidzieć w ustawie inne sposoby obrony społecznej przed sprawcami niebezpiecznych czynów zabronionych, jeżeli pociągnięcie ich do odpowiedzialności karnej nie jest możliwe ${ }^{7}$. Sposobem tym jest zastosowanie środka zabezpieczającego wobec sprawcy niepoczytalnego w chwili czynu. Warunki stosowania izolacyjnego środka zabezpieczającego w postaci umieszczenia w zamkniętym zakładzie leczenia psychiatrycznego kodeks karny określa w art. 93c pkt 1 (co do sprawcy umorzono postępowanie karne o czyn zabroniony popełniony w stanie niepoczytalności określonej w art. $31 \S 1$ ) oraz $93 \mathrm{~g} \S 1$ (istnieje wysokie prawdopodobieństwo, że popełni on ponownie czyn zabroniony o znacznej społecznej szkodliwości w związku z chorobą psychiczną lub upośledzeniem umysłowym) ${ }^{8}$.

Obie okoliczności wymagają wiadomości specjalnych, istnieje zatem konieczność powołania biegłego (art. 193 i 202 k.p.k.) zarówno co do istnienia niepoczytalności w chwili czynu i jej przyczyny, jak i co do tego, czy istnieje prawdopodobieństwo, że w związku ze stwierdzoną chorobą psychiczną lub upośledzeniem umysłowym osoba ta popełni ponownie czyn zabroniony o znacznej społecznej szkodliwości i czy prawdopodobieństwo to jest wysokie.

7 Zob. K. Krajewski, [w:] System Prawa Karnego, t. 7. Środki zabezpieczajace, red. L.K. Paprzycki, Warszawa 2015, s. 4 n.

8 Na marginesie tych rozważań warto zauważyć, że kodeks karny nie przewiduje możliwości zastosowania izolacyjnego środka zapobiegawczego w związku z niepoczytalnością, której przyczyną było inne zakłócenie czynności psychicznych (zob. art. 93g k.k.). 
Sąd na wniosek biegłych (art. 203 k.p.k.) kieruje oskarżonego na obserwację do zakładu psychiatrycznego, badając uprzednio, czy zebrane dowody wskazują na duże prawdopodobieństwo, że oskarżony popełnił przestępstwo ${ }^{9}$. Sąd, kierując oskarżonego na obserwację, określa miejsce $^{10}$ i czas jej trwania. Maksymalny czas trwania obserwacji, zgodnie z art. $203 \S 3$ k.p.k., nie może przekroczyć 8 tygodni w całym postępowaniu w danej sprawie. Ograniczenie czasu trwania obserwacji psychiatrycznej i ustanowienie wymagań co do poziomu udowodnienia zarzutu w toku postępowania karnego zostało wprowadzone skutkiem orzeczenia Trybunału Konstytucyjnego ${ }^{11}$, w którego uzasadnieniu napisano między innymi: ,Zaskarżony przepis, ograniczając korzystanie z konstytucyjnych wolności i praw, dokonuje tego w sposób na tyle nieprecyzyjny, a zarazem arbitralny i szeroki, że narusza samą istotę konstytucyjnie chronionej wolności”.

Co do obserwacji psychiatrycznej oskarżonego sytuacja jest o tyle bardziej skomplikowana niż w innych wypadkach, że oskarżony może mieć interes symulowania choroby psychicznej celem uniknięcia odpowiedzialności karnej. Okres 8 tygodni obserwacji może okazać się niewystarczający. Biegli mogą nie być w stanie jednoznacznie wypowiedzieć się co do poczytalności. Wówczas decyzja co do poczytalności i odpowiedzialności oskarżonego należy do sądu ${ }^{12}$.

${ }^{9}$ Wymagania co do ilości i jakości zebranych dowodów są w k.p.k. stopniowane. Do wszczęcia postępowania wymaga się uzasadnionego podejrzenia popełnienia przestępstwa (art. 303 k.p.k.), podobnie do przedstawienia zarzutów (art. 313 k.p.k.), do zastosowania zaś środków zapobiegawczych, podobnie jak do umieszczenia w zamkniętym zakładzie leczenia psychiatrycznego celem badania poczytalności, wymaga się, by zebrane dowody wskazywały na duże prawdopodobieństwo, że oskarżony popełnił przestępstwo (art. 249 k.p.k.).

${ }^{10}$ Miejsce określa się, biorąc pod uwagę stopień zabezpieczenia zakładu psychiatrycznego. Zob. rozporządzenie Ministra Zdrowia z dnia 2 grudnia 2004 roku w sprawie wykazu zakładów psychiatrycznych i zakładów leczenia odwykowego przeznaczonych do wykonywania obserwacji oraz sposobu finansowania obserwacji, a także warunków zabezpieczenia zakładów dla osób pozbawionych wolności (tekst jedn. Dz.U. z 2019 r. poz. 1708).

11 Wyrok Trybunału Konstytucyjnego z dnia 10 lipca 2007 roku, sygn. SK 50/06 (Dz.U. z 2007 r. Nr 128, poz. 903).

12 Można rozważać, jak sąd ma ocenić poczytalność przy braku wiadomości specjalnych. Praktycznie możliwe są trzy różne podejścia: sąd może ocenić poczytalność, 
Ustawa o ochronie zdrowia psychicznego dopuszcza leczenie w szpitalu psychiatrycznym bez zgody osoby, której dotychczasowe zachowanie wskazuje na to, że z powodu choroby psychicznej zagraża bezpośrednio własnemu życiu ${ }^{13}$ albo życiu lub zdrowiu innych osób (art. 23.1). Umieszczenie w szpitalu wymaga zgody sądu opiekuńczego wyrażonej w procedurze opisanej w ustawie o ochronie zdrowia psychicznego (art. $21 \mathrm{n}$.).

Jeżeli jednak dotychczasowe zachowanie osoby wskazuje, że z powodu zaburzeń psychicznych zagraża ona bezpośrednio swojemu życiu albo życiu lub zdrowiu innych osób, ale zachodzą wątpliwości, czy jest ona chora psychicznie, można ją umieścić bez zgody (ale na podstawie postanowienia sądu) w szpitalu celem wyjaśnienia tych wątpliwości (art. 24.1). Pobyt diagnostyczny nie może trwać dłużej niż 10 dni (art. 24.2) ${ }^{14}$. Dlaczego w tym wypadku tylko 10 dni, skoro w postępowaniu karnym jest aż 8 tygodni, czyli niemal sześć razy dłużej? Czy dla dokonania rozpoznania stosuje się tu inne procedury diagnostyczne niż w stosunku do podejrzanych o popełnienie przestępstwa? Nie wydaje się, bo nie ma ograniczenia w stosowaniu metod diagnostycznych w stosunku do podejrzanych o popełnienie przestępstwa ${ }^{15}$. Może zatem dlatego, że podejrzani o popełnienie przestępstwa mogą symulować chorobę psychiczną $\mathrm{i}$ trzeba podejrzenie o symulowanie choroby wyeliminować? A może, co wydaje się najbardziej prawdopodobne, twórcy ustawy

kierując się sugestiami zawartymi w niestanowczej opinii biegłych; może powrócić do domniemania poczytalności, przyjmując, że nie zostało ono obalone przez biegłych; może wybrać opcję, którą uznaje za korzystniejszą dla oskarżonego.

13 Zagrożenie własnemu życiu (próby samobójcze) według mnie nie jest dostatecznym powodem leczenia bez zgody. Samobójstwo nie jest w Polsce czynem niedozwolonym i nie widzę powodu, dla którego usprawiedliwione jest przymusowe przeciwdziałanie takiemu czynowi.

${ }^{14}$ Badanie spraw sądowych o umieszczenie w szpitalu psychiatrycznym celem badania diagnostycznego przeprowadził dr T. Pałdyna. Zob. Instytut Wymiaru Sprawiedliwości, Praktyka sądowa w zakresie stosowania wybranych instytucji prawnych zawartych $w$ ustawie o ochronie zdrowia psychicznego, Warszawa 2015. Raport na stronie internetowej IWS.

${ }^{15}$ Zastosowanie niektórych procedur w stosunku do podejrzanych, a także osób poddanych leczeniu psychiatrycznemu za zgodą sądu wymaga jednak dodatkowej zgody sądu. Zob. rozporządzenie Ministra Zdrowia z dnia 24 kwietnia 2012 roku (Dz.U. z 2010 r. poz. 494) w sprawie wykazu świadczeń zdrowotnych stwarzających podwyższone ryzyko dla pacjenta, których udzielenie wymaga zgody. 
o ochronie zdrowia psychicznego ustalili czas trwania badania wedle swej najlepszej wiedzy medycznej, uznając że 10 dni to czas wystarczający do ustalenia, czy człowiek jest chory czy zdrowy psychicznie. Nie rozważali, jak czas ten jest uregulowany w innych ustawach.

Pozbawienie wolności w celu diagnostycznym dopuszcza również kodeks postępowania cywilnego w sądowym postępowaniu o ubezwłasnowolnienie. Przyczyny uzasadniające całkowite ubezwłasnowolnienie określa kodeks cywilny w art. 13 w następujący sposób: ,jeżeli wskutek choroby psychicznej, niedorozwoju umysłowego albo innego rodzaju zaburzeń psychicznych, w szczególności pijaństwa lub narkomanii, nie jest w stanie kierować swym postępowaniem". Całkowite ubezwłasnowolnienie pozbawia osobę zdolności do czynności prawnych. Możliwe jest również ubezwłasnowolnienie częściowe (art. 16 k.c.), które ogranicza zdolność do czynności prawnych.

Ubezwłasnowolnienie orzeka sąd w postępowaniu nieprocesowym uregulowanym w art. 544n k.p.c. Artykuł $554 \S 1$ pozwala sądowi, jeżeli na podstawie opinii dwóch biegłych lekarzy uzna to za niezbędne, zarządzić oddanie osoby, której dotyczy wniosek o ubezwłasnowolnienie, na obserwację w zakładzie leczniczym na czas nie dłuższy niż sześć tygodni. W wyjątkowych wypadkach sąd może termin ten przedłużyć do trzech miesięcy.

Po pierwsze, należy zastanowić się, jakie konstytucyjne przesłanki pozwalają na czasowe pozbawienie wolności osoby, gdy złożono wniosek o jej ubezwłasnowolnienie, sprowadzające się do pozbawienia zdolności do czynności prawnych. Z pewnością nie jest to bezpieczeństwo ani porządek publiczny. Nie jest to również ochrona środowiska. Pozostaje więc zdrowie i moralność publiczna albo wolności i prawa innych osób. Wydaje się, że nie chodzi o zdrowie, bo przymusowe (bez zgody) leczenie, również psychiatryczne, nie zależy od zdolności do czynności prawnych. Również osoba w pełni zdolna do czynności prawnych może być leczona bez zgody, gdy są spełnione przesłanki zawarte w ustawie.

Gdy przyczyną ubezwłasnowolnienia jest pijaństwo lub narkomania, można doszukiwać się uzasadnienia ograniczenia prawa tej osoby, w tym jej wolności osobistej na potrzeby diagnozy, w moralności publicznej. Zapewne nie jest z moralnością publiczną zgodne trwonienie 
nawet własnego majątku na alkohol lub narkotyki, co w dalszej perspektywie naraża na szwank także porządek publiczny zagrożony przez osobę nietrzeźwą lub pozostającą pod wpływem narkotyków. Te same względy przemawiają za możliwością pozbawienia wolności na czas diagnozy osoby, o której ubezwłasnowolnienie wystąpiono z przyczyny innych zaburzeń psychicznych powiązanych z trwonieniem majątku, niebędących chorobą (na przykład uzależnienie od hazardu, zakupoholizm). Choroba psychiczna lub niedorozwój umysłowy są podstawą ubezwłasnowolnienia, gdy przejawiają się niezdolnością do rozsądnego kierowania własnymi sprawami majątkowymi lub rodzinnymi (ubezwłasnowolnienie skutkuje utratą władzy rodzicielskiej). W wypadku władzy rodzicielskiej chodzi o prawa innych osób, tych pozostających pod władzą osoby niezdolnej do jej sprawowania. A w wypadku majątku, gdy wyłącznie kwestie nierozsądnych rozporządzeń majątkowych są przyczyną wniosku o ubezwłasnowolnienie, jaka racja konstytucyjna uzasadnia podjęcie kroków w kierunku ograniczenia jej wolności, w tym wolności osobistej na czas diagnozy? Nie wiem.

I znowu - dlaczego podstawowy okres zarządzonego przez sąd badania to 6 tygodni, a maksymalny aż 3 miesiące, czyli wyraźnie dłużej niż w wypadku badania oskarżonego w kierunku ustalenia poczytalności w sprawie karnej? Istnieją dwa podstawowe problemy dotyczące pozbawienia wolności na potrzeby postawienia diagnozy co do istnienia zaburzeń (chorób) psychicznych: po pierwsze — w jakich sytuacjach w świetle Konstytucji RP wolno wprowadzać przepisy (rangi ustawowej) pozwalające na pozbawienie wolności w celu postawienia diagnozy, a po drugie - jak długi okres pozbawienia wolności w takim celu wydaje się konstytucyjnie dopuszczalny.

Odpowiedź na pierwsze pytanie musi odwołać się do treści art. 31 Konstytucji i zawartych tam przesłanek. Jeżeli nie potrafimy wskazać, która z konstytucyjnych przesłanek odnosi się do wprowadzonej ustawą możliwości pozbawienia wolności w celu postawienia diagnozy w zakresie zdrowia psychicznego, możliwość pozbawienia wolności nie jest uzasadniona konstytucyjnie. Wątpliwości dotyczą, według mnie, dwóch przypadków: ubezwłasnowolnienia i badania stanu zdrowia psychicznego osoby, która zagraża własnemu życiu (podejmowała próby samobójcze). 
W wypadku ubezwłasnowolnienia komentatorzy ${ }^{16}$, śladem orzeczeń Sądu Najwyższego ${ }^{17}$, wskazują, że pozbawienie wolności celem postawienia diagnozy może być dopuszczalne tylko wtedy, gdy podejrzewa się istnienie choroby psychicznej, inne zaburzenia psychiczne nie tworzą zatem dostatecznego uzasadnienia. Argument wydaje się rozsądny, tyle że wówczas nie jest potrzebny specjalny przepis w kodeksie postępowania cywilnego, gdyż podstawa pozbawienia wolności w celu diagnostycznym jest zawarta w ustawie o ochronie zdrowia psychicznego. Ustawa ta pozwala na pozbawienie wolności na okres do 10 dni celem postawienia diagnozy, czy osoba jest chora psychicznie, k.p.c. pozwala zaś nawet na 3 miesiące. Jedynym wytłumaczeniem wydaje się to, że k.p.c. jest ustawą wcześniejszą (z 1964 roku) niż ustawa o ochronie zdrowia psychicznego (z 1994 roku), więc gdy powstawał kodeks postępowania cywilnego, nie było możliwości prawnej zarządzenia przymusowej obserwacji w zakładzie leczniczym w celu diagnostycznym. A była potrzeba takiej obserwacji. Skonstruowano więc szczególny rodzaj pozbawienia wolności na potrzeby diagnostyczne w postępowaniu w sprawie ubezwłasnowolnienia.

Artykuł 24 ustawy o ochronie zdrowia psychicznego, pozwalający na badanie diagnostyczne w zakładzie zamkniętym bez zgody osoby, zawiera ograniczenie, że chodzi tylko o przypadki, gdy zachowanie takiej osoby wskazuje na to, że z powodu zaburzeń psychicznych zagraża bezpośrednio swojemu życiu lub życiu albo zdrowiu innych osób, a zachodzą wątpliwości, czy jest chora psychicznie. Badanie ma służyć

16 Zob. Kodeks postępowania karnego. Komentarz, red. K. Piasecki, Warszawa 1997, teza 1 do art. 554.

${ }^{17}$ Linia orzecznictwa Sądu Najwyższego jest co do tego stała. Obserwacja w zakładzie zamkniętym uznawana jest za środek wyjątkowy, dopuszczalny tylko w interesie osoby, która ma być ubezwłasnowolniona, gdy inne środki dowodowe okażą się wystarczające (postanowienie SN z dnia 6 maja 1971 roku, II CZ 51/71). Nie może zostać zarządzona na wniosek osoby, o której ubezwłasnowolnienie toczy się sprawa, celem wykazania, że jest psychicznie zdrowa (postanowienie SN z dnia 3 maja 1974 roku, ICZ 56/74). Zarządzenie obserwacji bez zgody osoby ubezwłasnowolnionej nie jest również możliwe w sprawie o uchylenie ubezwłasnowolnienia (postanowienie SA w Katowicach z dnia 8 marca 2001 roku, I ACa 1233/00). Wreszcie, zgodnie z postanowieniem SN z dnia 10 marca 1966 roku, II CR 32/64, „obserwację kliniczną może sąd zarządzić wtedy, gdy zaburzenia psychiczne zostaną przez biegłych stwierdzone, wymagają jednak sprawdzenia w zakładzie leczniczym, a nie wtedy, gdy zaburzeń nie ma i ich objawów nie stwierdza się". 
wyjaśnieniu tych wątpliwości. Samo przyjęcie do szpitala w celu diagnostycznym bez zgody wymaga postępowania przed sądem opiekuńczym, takiego jak przy przyjęciu do szpitala celem leczenia bez zgody. Jak się ma do tego restrykcyjnego uregulowania sytuacja dopuszczona w toku postępowania o ubezwłasnowolnienie - znacznie mniej restrykcyjna — i czy powinna być utrzymana? Moim zdaniem nie. Wątpliwości, czy osoba, o której ubezwłasnowolnienie toczy się postępowanie, niemożliwe do usunięcia podczas zwykłego badania przez lekarza psychiatrę lub neurologa oraz psychologa (art. $553 \S 1$ k.p.c.), powinny tyko wtedy umożliwiać oddanie jej pod obserwację psychiatryczną, gdy spełnione są przesłanki zawarte w art. 24 ustawy o ochronie zdrowia psychicznego (osoba zagraża bezpośrednio swojemu życiu albo życiu lub zdrowiu innych osób, a zachodzą wątpliwości, czy jest ona chora psychicznie) i nie na dłużej niż przewidziany w tej ustawie okres 10 dni. Inne okoliczności (w szczególności względy majątkowe) nie mogą uzasadniać pozbawienia wolności w celu diagnostycznym, nie odpowiadają bowiem zasadzie proporcjonalności.

Jeżeli ustawa o ochronie zdrowia psychicznego przewiduje $10 \mathrm{dni}$ na wydanie diagnozy, to nie ma powodu, by okres ten wydłużać w toku postępowania o ubezwłasnowolnienie. Wydaje się natomiast, że w toku postępowania karnego dłuższą obserwację może uzasadniać potrzeba wyeliminowania symulowania choroby psychicznej przez oskarżonego.

\section{Bibliografia}

Kodeks postępowania karnego. Komentarz, K. Piasecki, Warszawa 1997.

Krajewski K., [w:] System Prawa Karnego, t. 7. Środki zabezpieczające, red. L.K. Paprzycki, Warszawa 2015.

Pałdyna T., Praktyka sądowa $w$ zakresie stosowania wybranych instytucji prawnych zawartych w ustawie o ochronie zdrowia psychicznego, Instytut Wymiaru Sprawiedliwości, Warszawa 2015. 


\title{
Deprivation of freedom in order to examine a person's mental state in Polish law
}

\begin{abstract}
Summary
The subject of these considerations is the deprivation of freedom ordered to diagnose the state of an individual's/person's mental health. Polish law provides for such a diagnostic deprivation of freedom in the event of a suspected offense with a simultaneous doubt as to the person's sanity at the time of the committing the act (Code of Criminal Procedure), doubt as to mental illness beings a cause of behavior threatening one's own life or health, or the lives of others (Act on the Protection of Mental Health) and the existence of a mental illness as a reason for incapacitation (Code of Civil Procedure). These legal institutions differ as for constitutional justification (Article 31 point 3 ) of the Polish Constitution) and their permissible duration. These differences are the main subject of the analysis. Particularly doubtful seems the possibility of diagnostic deprivation of freedom provided for in the proceedings on incapacitation, as to its duration (it may last up to 3 months).
\end{abstract}

Keywords: deprivation of freedom, mental state, sanity, incapacitatio. 